\title{
DIGITAL AND PALMAR DERMATOGLYPHICS IN MYOCARDIAL INFARCTION
}

\author{
Manara $\mathrm{A}^{1}$, Habib $\mathrm{MA}^{2}$, Rahman $\mathrm{MA}^{3}$, Ayub $\mathrm{M}^{4}$, Begum $\mathrm{N}^{5}$, Hossain $\mathrm{S}^{6}$
}

\begin{abstract}
Introduction: Dermatoglyphics pattern is feature with which human takes birth. As a diagnostic aid, it is now well established in a number of diseases which have a strong hereditary basis. The aetiology of coronary heart diseases is believed to be multi-factorial with genetics playing an important role.
\end{abstract}

Objective: The present study was designed to make an observation of the usefulness of dermatoglyphic pattern in serving as a predictor for myocardial infarction among Bangladeshi male who were non relative to each other.

Place of study: The study was conducted in the Department of Anatomy, Bangabandhu Sheikh Mujib Medical University (BSMMU), Dhaka, Bangladesh, between October 2003 and February 2005.

Method: Inking method was used for taking finger and palm prints. Dermatoglyphic prints of five fingers and palm of both hands of sixty individuals were collected. Of them dermatoglyphic prints of both hands of 30 myocardial infarction (MI) male patients non relative to each other were selected as patients and same of 30 normal male having no myocardial infarction and having no family history of MI were selected as control.

The dermatoglyphics of each hand of the patients were compared with those of the controls for: a) frequencies of different finger ridge patterns of the five fingers; b) total finger ridge count (TFRC); c) a-b, b-c, and c-d ridge counts of each hand; d) a-t-d angle; e) frequency of palmar ridge pattern and $f$ ) frequencies of different palmar creases.

Result: The results of the controls confirmed more or less to the ethnic trends of the normal Bangladeshi. In case of finger dermatoglyphics, the MI patients showed higher frequencies of whorl patterns but lower frequencies of ulnar loop, radial loop and arch patterns than the controls. The mean total finger ridge count of the MI patients was lower than that of the controls $(p>0.05)$. In case of palmar dermatoglyphics a-b, $c-d$ ridge counts was higher and b-c ridge counts was lower in the MI patients than in the controls. Mean a-t-d angle was wider in the MI patients than that of the controls. Palmar patterns and creases showed no significant difference except transitional crease of the right hand that was significantly lower in MI patients than controls.

Conclusion: Result of this study may be used to standardize the dermatoglyphic pattern of Bangladeshi population and to identify person susceptible to MI.

Keywords: Dermatoglyphic pattern, susceptibility, myocardial infarction (MI)

\section{Introduction}

Skin is composed of epidermal and dermal layers. The junction of dermis and epidermis is irregular and projections of the dermis are called papillae that interdigitate with evaginations of the epidermis known as epidermal ridges ${ }^{1}$. Ridged skin is not strictly confined to the palmer and plantar surfaces, but also over the tips of digits, on the digital margins, along the margins of palm and sole. Though dermatoglyphics initially started as study of finger print analysis, the creases on the palms have also been incorporated into the domain of dermatoglyphics. The ridges develop between the tenth and nineteenth intrauterine weeks, forming different patterns. Since then they remain unchanged except in its absolute size, throughout the life $\mathrm{e}^{2,3}$.

Myocardial infarction is one of the most common diagnoses in hospitalized patients in industrialized countries. The mortality rate with acute infarction is approximately $30 \%$, more than half of these deaths occur before the attacked individual reaches the hospital ${ }^{4}$. A correlation between dermatoglyphics and certain diseases was suggested 30 years ago, almost half a century after Sir Francis Galton had linked dermatoglyphics with genetics 5 . However, the prints do not establish a diagnosis by themselves but can prompt the physician to make a more thorough examination than usual to find out any hidden abnormality. The diagnosis of myocardial infarction is often difficult due to scarcity of physical signs, specially in rural areas of developing countries where diagnostic facilities are lacking ${ }^{6}$. It may be more contributory to the preventive aspect of the disease.

1. Lt Col Anju Manara MBBS, MS, Associate Professor, Department of Anatomy, AFMC; 2. Colonel Md Ahsan Habib MBBS, M Phil, Professor, Department of Anatomy, AFMC; 3. Lt Col Md Azizur Rahman MBBS, M Phil, Associate Professor, Department of Anatomy, AFMC; 4. Lt Col Mahmuda Ayub MBBS, M Phil, Associate Professor, Department of Anatomy, AFMC; 5. Lt Col Nasrin Begum MBBS, M Phil, Associate Professor, Department of Anatomy, AFMC; 6. Maj Sharmin Hossain MBBS, M Phil, Assistant Professor, Department of Anatomy, AFMC. 
Apart from the correlation of dermatoglyphics with various diseases there have been abundant works around the globe on various aspects of dermatoglyphics including its relationship with constitutional traits ${ }^{3,7}$. Race difference in the occurrence of different dermatoglyphic patterns is an important aspect of physical anthropology as well as of genetics $^{8}$. Various studies were conducted at different parts of world to find the pattern of dermatoglyphics in MI patients so that an warning can be given to those people of vulnerable group ${ }^{3,4-12}$. This study was designed to observe the usefulness of dermatoglyphics as a predictor for myocardial infarction among individuals living in Bangladesh.

\section{Materials and Methods}

The study was conducted in the Department of Anatomy, Bangabandhu Sheikh Mujib Medical University (BSMMU), Dhaka, Bangladesh, between October 2003 and February 2005. Thirty (30) male patients undergoing treatment of myocardial infarction (MI) in the Cardiology ward of the Combined Military Hospital $(\mathrm{CMH})$, Dhaka were selected for the study as case group (identified as Patient). Another 30 normal male having no MI and having no family history of MI, ishchaemic heart disease or hyperlipidaemia and non relative to each other were selected as control. Purpose was explained to the selected subjects and only those who volunteered to be studied were included in the study. Dermatoglyphic prints of five fingers and palm of both hands of sixty individuals were collected. An effort was made to keep the age range as close as possible of the patients. Persons with any disease except MI which affect dermatoglyphics, like diabetes mellitus, allergic dermatitis in fingers and palms, gross congenital anomalies, asthma, any type of carcinoma, history of rubella during intrauterine life and congenital heart disease were excluded. A carefully structured assessment sheet was used for selecting the patients and controls.

The present study was carried out on dermatoglyphic prints of five fingers and palm of both hands of sixty individuals. Thus $(30 \times 2) 60$ palm prints and ( $30 \times 10)$ 300 finger prints of the patients and $(30 \mathrm{X} 2) 60$ palm prints and $(30 \mathrm{X} 10) 300$ finger prints of controls were collected. So a total of $60+60=120$ palm prints and 300 $+300=600$ finger prints were obtained. All the dermatoglyphic prints were examined under mounted hand lens and dissecting microscope. Data were expressed as mean \pm SD and categorical data in percentage $(\%)$ and frequency (f). Chi Squared test with Yate's correction (where applicable) and Fisher's Exact test were used for analysis the qualitative values. For analysis the quantitative values, Unpaired Student's ' $t$ ' test was used. Statistical analyses were done using a computer-based programmer, Statistical Package for Social Science (SPSS)-12. Differences were considered significant if $p$ values were less than 0.05 .

\section{Results}

The important dermatoglyphic findings were compared between the two groups. Frequencies of different patterns on each hand and on both hands combined are presented in table-I.

The whorl pattern was higher in frequency but ulnar loop, radial loop and arch patterns were lower in frequency in

Table-I: Frequencies of different digital patterns in the hands of the study groups

\begin{tabular}{|l|l|l|l|l|l|l|}
\hline \multirow{2}{*}{$\begin{array}{l}\text { Digital } \\
\text { pattern }\end{array}$} & \multicolumn{2}{|c|}{ Right hand } & \multicolumn{2}{c|}{ Left hand } & \multicolumn{2}{c|}{ Both hands } \\
\cline { 2 - 7 } & $\begin{array}{c}\text { Control } \\
\mathbf{n}=\mathbf{1 5 0}\end{array}$ & $\begin{array}{c}\text { Patient } \\
\mathbf{n = 1 5 0}\end{array}$ & $\begin{array}{c}\text { Control } \\
\mathbf{n = 1 5 0}\end{array}$ & $\begin{array}{c}\text { Patient } \\
\mathbf{n = 1 5 0}\end{array}$ & $\begin{array}{c}\text { Control } \\
\mathbf{n = 3 0 0}\end{array}$ & $\begin{array}{c}\text { Patient } \\
\mathbf{n = 3 0 0}\end{array}$ \\
\hline $\begin{array}{c}\text { Whorl } \\
\text { f (\%) }\end{array}$ & $69(46.00)$ & $78(52.00)$ & $65(43.33)$ & $70(46.67)$ & $134(44.67)$ & $148(49.33)$ \\
\hline $\begin{array}{c}\text { Ulnar loop } \\
\text { f (\%) }\end{array}$ & $72(48.00)$ & $67(44.67)$ & $76(50.67)$ & $76(50.67)$ & $148(49.33)$ & $143(47.67)$ \\
\hline $\begin{array}{c}\text { Radial loop } \\
\text { f (\%) }\end{array}$ & $01(0.67)$ & $02(1.33)$ & $06(4.00)$ & $03(2.00)$ & $07(2.33)$ & $05(1.67)$ \\
\hline $\begin{array}{c}\text { Arch } \\
\text { f (\%) }\end{array}$ & $08(5.33)$ & $03(2.00)$ & $03(2.00)$ & $01(0.67)$ & $11(3.67)$ & $04(1.33)$ \\
\hline
\end{tabular}

* No significant difference between the groups (patients and controls) for any of the variables.

the MI patients than those in the control subjects. No statistically significant difference was present between the MI patients and the control subjects (Table-II). The mean total finger ridge count of both hands of MI patients was lower than the control subjects. In the right hand of the MI patients the mean total finger ridge count was higher and in the left hand it was lower than the control subjects.

Table-II: Total finger ridge counts in the study groups

\begin{tabular}{|l|l|l|l|}
\hline Group & Control & Patient & p value \\
\hline $\begin{array}{c}\text { Both hand } \\
\text { Range } \\
\text { Mean } \pm \text { SD }\end{array}$ & $\begin{array}{l}59-246 \\
162.7 \pm 48.62\end{array}$ & $\begin{array}{l}80-207 \\
161.37 \pm 29.05\end{array}$ & $>0.05$ \\
\hline $\begin{array}{l}\text { Right hand } \\
\text { Range } \\
\text { Mean } \pm \text { SD }\end{array}$ & $\begin{array}{l}26-122 \\
80.23 \pm 25.06\end{array}$ & $\begin{array}{l}44-106 \\
80.37 \pm 15.22\end{array}$ & $>0.05$ \\
\hline $\begin{array}{l}\text { Left hand } \\
\text { Range } \\
\text { Mean } \pm \text { SD }\end{array}$ & $\begin{array}{l}25-128 \\
82.30 \pm 25.30\end{array}$ & $\begin{array}{l}36-107 \\
80.43 \pm 16.33\end{array}$ & $>0.05$ \\
\hline
\end{tabular}


Table-III: Range and mean of $a-b, b-e$ and $c-d$ ridge counts in the study groups

\begin{tabular}{|c|l|l|l|l|l|l|}
\hline \multirow{2}{*}{ Variable } & \multicolumn{2}{|l|}{ a-b ridge counts } & \multicolumn{2}{l|}{ b-c ridge counts } & \multicolumn{2}{l|}{ c-d ridge counts } \\
\cline { 2 - 7 } & Control & Patient & Control & Patient & Control & Patient \\
\hline $\begin{array}{c}\text { Right hand } \\
\text { Range } \\
\text { Mean } \pm S D\end{array}$ & $\begin{array}{l}25-52 \\
(36.97 \pm 6.84)\end{array}$ & $\begin{array}{l}29-41 \\
(37.30 \pm 3.97)\end{array}$ & $\begin{array}{l}16-35 \\
(26.03 \pm 5.55)\end{array}$ & $\begin{array}{l}16-36 \\
(25.63 \pm 5.60)\end{array}$ & $\begin{array}{l}18-49 \\
(36.16 \pm 7.31)\end{array}$ & $\begin{array}{l}23-49 \\
(35.03 \pm 6.70)\end{array}$ \\
\hline $\begin{array}{c}\text { Left hand } \\
\text { Range } \\
\text { Mean } \pm S D\end{array}$ & $\begin{array}{l}29-48 \\
(38.67 \pm 5.35)\end{array}$ & $\begin{array}{l}26-48 \\
(39.47 \pm 5.12)\end{array}$ & $\begin{array}{l}16-40 \\
(26.83 \pm 6.84)\end{array}$ & $\begin{array}{l}17-35 \\
(25.07 \pm 5.52)\end{array}$ & $\begin{array}{l}02-46 \\
(30.80 \pm 11.02)\end{array}$ & $\begin{array}{l}17-47 \\
(32.70 \pm 6.13)\end{array}$ \\
\hline $\begin{array}{c}\text { Both hands } \\
\text { Range } \\
\text { Mean } \pm \mathrm{SD}\end{array}$ & $\begin{array}{l}55-95 \\
(75.63 \pm 10.5)\end{array}$ & $\begin{array}{l}55-93 \\
(76.60 \pm 8.08)\end{array}$ & $\begin{array}{l}34-72 \\
(52.87 \pm 11.31)\end{array}$ & $\begin{array}{l}33-70 \\
(50.7 \pm 10.18)\end{array}$ & $\begin{array}{l}36-95 \\
(66.97 \pm 13.4)\end{array}$ & $\begin{array}{l}43-95 \\
(67.73 \pm 12.21)\end{array}$ \\
\hline
\end{tabular}

* No significant differences $(\mathrm{p}>0.05)$ between control and patient group.

Table-IV: Range and mean of a-t-d angle in the study groups

\begin{tabular}{|c|l|l|l|}
\hline Variables & $\begin{array}{l}\text { Control } \\
\mathbf{n = 3 0}\end{array}$ & $\begin{array}{l}\text { Patient } \\
\mathbf{n = 3 0}\end{array}$ & p value \\
\hline $\begin{array}{c}\text { Right hand } \\
\text { Range }\end{array}$ & $29.00^{\circ}-58.00^{\circ}$ & $29.00^{\circ}-50.50^{\circ}$ & $>0.05$ \\
Mean $\pm \mathrm{SD}$ & $38.56^{\circ} \pm 5.60^{\circ}$ & $39.60^{\circ} \pm 4.90^{\circ}$ & \\
\hline Left hand & & & \\
Range & $27.00^{\circ}-53.50^{\circ}$ & $27.50^{\circ}-58.00^{\circ}$ & $>0.05$ \\
Mean $\pm \mathrm{SD}$ & $38.32^{\circ} \pm 6.02^{\circ}$ & $41.15^{\circ} \pm 7.10^{\circ}$ & \\
\hline
\end{tabular}

In palmar dermatoglyphics MI patients showed higher a$\mathrm{b}$ and $\mathrm{c}-\mathrm{d}$ ridge counts and lower $\mathrm{b}-\mathrm{c}$ ridge counts than in the control subjects (Table-III). When considered right

Table-V: Frequencies of different palmar patterns in study groups

\begin{tabular}{|c|c|c|c|c|c|c|c|c|c|}
\hline \multirow{2}{*}{$\begin{array}{l}\text { Palmar } \\
\text { area }\end{array}$} & \multicolumn{3}{|c|}{ Right hand } & \multicolumn{3}{|l|}{ Left hand } & \multicolumn{3}{|c|}{ Both hands } \\
\hline & $\begin{array}{l}\text { Control } \\
\mathrm{n}==\mathbf{3 0}\end{array}$ & $\begin{array}{c}\begin{array}{c}\text { Patient } \\
\mathbf{n}=\mathbf{3 0}\end{array} \\
\end{array}$ & $\begin{array}{l}\mathbf{p} \\
\text { value }\end{array}$ & $\begin{array}{c}\begin{array}{c}\text { Control } \\
\mathbf{n}==\mathbf{3 0}\end{array} \\
\end{array}$ & $\begin{array}{l}\text { Patient } \\
\mathrm{n}=\mathbf{3 0}\end{array}$ & $\begin{array}{l}\mathbf{p} \\
\text { value }\end{array}$ & $\begin{array}{c}\begin{array}{c}\text { Control } \\
\mathrm{n}==60\end{array} \\
\end{array}$ & $\begin{array}{l}\text { Patient } \\
n=60\end{array}$ & $\begin{array}{l}p \\
\text { value }\end{array}$ \\
\hline I $\mathrm{f}(\%)$ & $00(00)$ & $01(3.33)$ & $>0.05$ & $00(00)$ & $01(3.33)$ & $>0.05$ & $00(00)$ & $02(3.33)$ & $>0.05$ \\
\hline II $\mathrm{f}(\%)$ & $3(10)$ & $5(16.67)$ & $>0.05$ & $2(6.67)$ & $4(13.33)$ & $>0.05$ & $05(8.33)$ & $09(15.0)$ & $>0.05$ \\
\hline $\begin{array}{l}\text { III } \\
\text { f(\%) }\end{array}$ & $18(60)$ & $23(76.67)$ & $>0.05$ & $15(50)$ & $14(46.67)$ & $>0.05$ & $33(55.0)$ & $37(61.67)$ & $>0.05$ \\
\hline $\begin{array}{l}\text { IV } \\
f(\%)\end{array}$ & $17(56.67)$ & $17(56.67)$ & $>0.05$ & $19(63.33)$ & $19(63.33)$ & $>0.05$ & $36(60.0)$ & $36(60.0)$ & $>0.05$ \\
\hline $\begin{array}{l}V^{\prime} \\
f(\%)\end{array}$ & $7(23.33)$ & $6(20)$ & $>0.05$ & $7(23.33)$ & $7(23.33)$ & $>0.05$ & $14(23.33)$ & $13(21.67)$ & $>0.05$ \\
\hline
\end{tabular}

Table-VI: Frequencies of different palmar creases in study groups

\begin{tabular}{|l|l|l|l|l|l|l|}
\hline \multirow{2}{*}{ Palmer Creases } & \multicolumn{2}{|c|}{ Right hand } & \multicolumn{3}{c|}{ Left hand } \\
\cline { 2 - 7 } & $\begin{array}{l}\text { Control } \\
\mathbf{n = 3 0}\end{array}$ & $\begin{array}{l}\text { Patient } \\
\mathbf{n}=\mathbf{3 0}\end{array}$ & $\begin{array}{l}\mathbf{p} \\
\text { value }\end{array}$ & $\begin{array}{l}\text { Control } \\
\mathbf{n = 3 0}\end{array}$ & $\begin{array}{l}\text { Patient } \\
\mathbf{n}=\mathbf{3 0}\end{array}$ & $\begin{array}{l}\mathbf{p} \\
\text { value }\end{array}$ \\
\hline $\begin{array}{l}\text { Simian creases } \\
\mathrm{f}(\%)\end{array}$ & $1(3.33 \%)$ & $2(6.67 \%)$ & $>0.05$ & $3(10.00 \%)$ & $2(6.67 \%)$ & $>0.05$ \\
\hline $\begin{array}{l}\text { Sydney creases } \\
\mathrm{f}(\%)\end{array}$ & $2(6.67 \%)$ & $3(10.00 \%)$ & $>0.05$ & $2(6.67 \%)$ & $3(10.00 \%)$ & $>0.05$ \\
\hline $\begin{array}{l}\text { Transitional creases } \\
\mathrm{f}(\%)\end{array}$ & $9(30.00)$ & $2(6.67 \%)$ & $<0.05$ & $6(20.00 \%)$ & $1(3.33 \%)$ & $>0.05$ \\
\hline
\end{tabular}

and left hand separately the right hands of the MI patients showed higher $a-b$ and lower counts in b$c$ and $\mathrm{c}-\mathrm{d}$ ridge counts than in the control subjects. The left hands of the MI patients showed higher $\mathrm{a}-\mathrm{b}$ and $\mathrm{c}-\mathrm{d}$ and lower counts in b-c ridge counts than in the control subjects. No statistically significant difference was present between the MI patients and the control subjects. The mean a-t-d angle was wider in the patients than in the controls (table-IV). When right and left hands were considered together the palmar pattern had the following decreasing orders of frequency (in controls : IV, III.,V, II, I and in patients : III, IV, V, II, I). When compared with the controls the patients had higher frequency on area III., II, I and lower frequency on area $\mathrm{V}$ (table-V). These however showed no statistical significant difference $(p>0.05)$. The frequencies of Simian, Sydney and Transitional creases in MI patients and in controls are shown in table -VI. The simian crease was present on four hands of both in the MI patients and in the control subjects. In the control subjects the Sydney crease was present on four hands. In the MI patient this crease was present on six hands. The MI patients showed lower frequency of transitional crease than the control subjects. In the right hand this difference was significant.

\section{Discussion}

The scientific study of papillary ridges of the hands and feet is credited as the beginning with the work of Purkinje in 1823. Since then scientists are searching to find its relation to 
identity of an individual and relation of susceptibility to killer diseases ${ }^{2,3}$.

In this study, dermatoglyphic of healthy male individual (control group) showed the decreasing order of sequence of frequencies as ulnar loop (49.33\%), whorl (44.67\%), arch $(3.67 \%)$ and then radial loop (2.33\%). Shamim in a study on Bangladeshi male found the same sequence of frequencies of pattern ${ }^{13}$. Jalali et al in a study in Iran observed whorl in $45.5 \%$ of healthy individual and $50.7 \%$ had loop 9 . In another study conducted among Indian healthy population Kumar et al observed $61.2 \%$ ulnar loop, 2.5\% radial loop and 31.9\% whorl ${ }^{5}$. More than half a century ago Mavalwala et al observed ulnar loop as the most frequent pattern $(49.08 \%)$ among the normal people of New Britain ${ }^{11}$. Whorl pattern was observed in $36.55 \%$ of subjects. In a recent study conducted in Tunisia loop pattern was observed in $79.8 \%$ male persons ${ }^{12}$. Observing the variation of pattern of fingerprints von Mensvoort tried to 'map the world' compiling the reports from 12 countries of the world ${ }^{14}$. von Mensvoort made an average of available data and observed ulnar loop (51.37\%) as the most frequent available dermatoglyphic pattern followed by whorl $(40.86 \%)$.

Morgan LY in a study on 107 normal Bangladeshi and Arefin $\mathrm{M}$ on 30 normal Bangladeshi including both male and female observed the similar sequence of frequencies with some variation of percentages ${ }^{15,16}$. This difference in pattern sequence may be due to racial variation or small population samples in those studies on Bangladeshi people.

In the present study in MI patients' whorl pattern was found in higher frequency and ulnar loop, radial loop and arch pattern in lower frequency than in controls. But those differences were not statistically significant $(p>0.05)$. Dhall et al studied on Indian myocardial infarction patients and observed significantly higher incidence of whorls $(p<0.001)$ and incidence of loops was relatively lower $(p<0.01)$ compared to control subjects $^{6}$. In that study Loop and whorls were further compared in individual digits. All the digits in heart patients showed lower incidence of loops and higher incidence of whorls. Whorls were observed significantly higher in patient in only right thumb, right little finger and left little finger. Loops were significantly less in right thumb and left ring finger in heart patients.

Rashed et al observed dermatoglyphic pattern in 834 Japanese subjects (100 MI patients) and found that individuals with MI had a significantly higher frequency of true whorls and a correspondingly lower frequency of ulnar loop than the control group ${ }^{17}$. In separate study conducted in India, Rao reported that persons who have predominant whorls in finger prints had higher incidence of widespread arterial and venous thrombosis and Bhatt observed significantly higher incidence of whorls and lower incidence of loops in patients of $\mathrm{MI}^{6}$. The later also reported significant difference in control and patients in the incidence of whorls and loops in all the individual fingers.

In the present study differences in patients from controls regarding total finger ridge counts (TERC) were not significant in case of both hands combined and also in right hand and left hand separately. Rashed et al observed much higher $(p<0.05)$ total as well as absolute ridge counts in patients of MI than the control group among Japanese ${ }^{17}$. Similar trends were observed in analyses by digit and by hand.

The MI patients of this study showed higher a-b and c-d ridge counts and lower b-c ridge counts than the control subjects. Of course, differences showed no statistical significance $(\mathrm{p}>0.05)$. When considered right and left hand separately the right hands of the MI patients showed higher count in $a-b$ and lower count in b-c and c-d ridge counts than the control subjects. Left hand of the MI patients showed higher count in a-b and c-d but lower in b-c ridge counts than the control subjects $(p>0.05)$. The values of control group of study conducted by Inamdar et al were very close to those of the present study and the author observed significant relation of the ridge count to carcinoma cervix ${ }^{18}$.

In the present study, the mean or average a-t-d angle in the control subjects was $38.44^{\circ}$. Kumar et $\mathrm{al}^{5}$ found that the average value of the a-t-d angle in normal healthy Indian children was $44.5^{\circ}$. David observed that the mean a-t-d angle in 33 healthy subjects, aged 4-7 year in England $94.3^{\circ}$ and the mean a-t-d angle in 956 healthy subjects, aged 8 years and above in England was $84.99^{\circ}{ }^{19}$.

In the present study, the palmar pattern of the palmar area in the controls had the following decreasing order of frequency: IV, III, V, II, I. Shamim observed in his study the decreasing order of frequency of palmar pattern in case of control was as follows: III, IV, V, II, I ${ }^{13}$. Kumar et al found highest frequency of palmar pattern in the fourth interdigital area in healthy Indian children. In his study the decreasing order of frequency of palmar pattern was : IV, III, V, I, II ${ }^{4}$. No significant difference in frequency of palmar pattern was found in the present study between the MI patients and the control subjects. The MI patients had higher frequency of palmar pattern in the area: III, II, I and lower frequency of palmar pattern in the area $\mathrm{V}$ than that of the control subjects.

Equal number of Simian creases (4 in each) was observed in both control and patient groups of the reported study. Sydney creases were observed in 4 and 6 persons respectively in control and patient group 
$(\mathrm{p}>0.05)$. Statistically significant less number of transitional creases was observed in right hand of MI patients $(p<0.05)$ than control. It was also less in left hand; but the difference was statistically not significant ( $>0.05$ ). In a study among Korean population Hwang et al observed $14.1 \%$ and $3.6 \%$ of Simian and Sydney creases respectively in normal male. The author observed significant relations of these with Rheumatoid arthritis patients ${ }^{20}$.

\section{Conclusion}

Prevention is always better than cure. Dermatoglyphics is a very simple and economical technique. By this human being can easily be grouped as per susceptibility to a particular disease. This study revealed that persons of control group with whorl patter of dermatoglyphics and lower frequencies of transitional crease in the right hand were the sufferer of MI. So these dermatoglyphic pattern may be a good indicator of MI susceptibility.

\section{References}

1. Mescher AL. Junqueira's Basic Histology. 12th ed. USA: McGrawHill Companies Inc; 2010.p. CD Chapter-Skin.

2. Kucken M, Newell AC. Fingerprint formation. Journal of Theoretical Biology 2005; 235:71-85.

3. Ramani P, Abhilash PR, Sherlin HJ, Anuja N, Premkumar P, Chandrasekar T, Sentamilselvi G, Janaki VR. Conventional Dermatoglyphics -Revived Concept : A Review. International Journal of Pharma and Bio Sciences 2011 July-September; 2(3): B446-B458.

4. Fausi AS, Kasper DL, Longo DL, et al. Herrison's Principles of Internal Medicine Volume II. 17th ed. New York: McGraw-Hill; 2008.p.1532.

5. Kumar S, Mangal BD, Kumar N. Dermatology in Healthy Indian Children- An analysis of Finger Prints, Palm Prints, Axial Triradil and 'atd' Angle, Sole and Toe Prints. Indian Journal of Paediatrics 1974;41(318): 249-256.

6. Dhall U, Rathee SK, Dhall A, Sharma BD. Utility of Fingerprints In
Myocardial Infarction Patients. Journal of the Anatomical Society of India 2000; 49(2) : 153-154

7. Ekanem EP, Eluwa MA, Udoaffah GU, Ekanem TB, Akpantah AO. Digital Dermatoglyphic Patterns Of Annang Ethnic Group in Akwa Ibom State Of Nigeria. The Internet Journal of Biological Anthropology 2009; 3(1).

8. Mazur ES, Sidorenko AG. Dermatoglyphics in the prognostication of constitutional and physical traits in humans. Sud Med Ekspert 2009 July-August; 52(4):18-20.

9. Jalali F, Hajian-Tilaki KO. A Comparative Study Of Dermatoglyphic Patterns In Patients With Myocardial Infarction And Control Group. Acta Medica Iranica 2001; 40(3); 187-191.

10. Anderson MW, Haug PJ, Critchfield G. Dermatoglyphic feature of myocardial infarction patients. American Journal of Physical Anthropology 1981; 55 (4): 523-527.

11. Mavalwala J, Swindler DR, Hunt Jr EE. The Dermatoglyphics of the West Nakanai of New Britain. American Journal of Anthropology 1963 September; 21(3): 335-340.

12. Namouchi I. Anthropological significance of dermatoglyphic trait variation: an intra-Tunisian population analysis. International Journal of Modern Anthropology 2011; 4 : 12 - 27

13. Shamim KM. Dermatoglyphics in diabetes mellitus (Thesis). Dhaka: Institute of Postgraduate Medicine and Research; 1988.

14. Van Mensvoot M. Heand Research: Discover the Language of Hand. Fingerprint World-Map. Hand in News 2011 May 11. Available at; http://www.handresearch.com

15. Morgan LY. Digital dermatoglyphics of 107 Bengalis. Amerian Journal of Anthropology 1979; 50(2): 259-261.

16. Arefin M.. Dermatoglyphics in Bangladeshi patients with congenital heart disease (Thesis). Dhaka: Institute of Postgraduate Medicine and Research; 1996.

17. Rashad MN, Mi MP, Rhoads G. Dermatoglyphic studies of myocardial infarction patients. Hum Hered 1978; 28(1):1-6.

18. Inamdar VV, Vaidya, Kulkarni P, et al. Dermatoglyphics In Carcinoma Cervix. Journal of Anatomical Scociety of India 2006; 55(1): 57-59.

19. David TJ. The corrected atd angle. Human Heredity 1981; 31(5): 283-5.

20. Hwang S, Chung M, Park J, Suh C. Dermatoglyphic Characteristics of Patients with Rheumatoid Arthritis. Korean J Phys Anthropol 2005; 18(4): 1-7. 